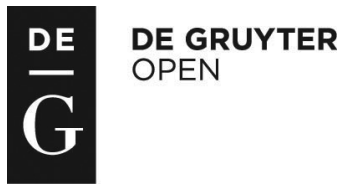

\title{
GENETIC RELATIONSHIPS AMONG LINEAR TYPE TRAITS AND MILK PRODUCTION TRAITS OF HOLSTEIN DAIRY CATTLE
}

\author{
Mehdi Bohlouli ${ }^{1 \star}$, Sadegh Alijani², Mehran Rahimi Varposhti ${ }^{3}$ \\ ${ }^{1}$ Young Researchers and Elite Club, Tabriz Branch, Islamic Azad University, Tabriz, Iran \\ ${ }^{2}$ Department of Animal Science, University of Tabriz, Tabriz, Iran \\ ${ }^{3}$ Arian Delta Gene Company \\ •Corresponding author: m.bohlouli@tabrizu.ac.ir
}

\begin{abstract}
The aim of this study was to estimate genetic relationships among milk production and linear type traits of Holstein dairy cattle from seven herds in Isfahan province of Iran. Phenotypic data was collected from 2004 to 2012 and included milk yield (MY), fat yield (FY) and protein yield (PY) for first three lactations, six body traits (stature, ST; chest width, CW; body depth, BD; angularity, AN; rump angle, RA; rump width, RW), three feet and legs traits (rear legs side view, RLSV; rear legs rear view, RLRV; foot angle, FA) and eight udder traits (fore udder attachment, FUA; rear udder height, RUH; rear udder width, RUW; central ligament, CL; udder depth, UD; fore teat placement, FTP; rear teat placement, RTP; teat length, TL). The number of animals for each linear type trait was 3505. Multi-trait animal models were used to estimate the (co)variance components based on restricted maximum likelihood method (REML) using WOMBAT software. Heritability estimates of first, second and third lactations for MY were $0.28,0.41$ and 0.36 ; for FY were 0.22 , 0.23 and 0.36 and for PY were $0.31,0.33$ and 0.25 , respectively. The heritability estimates ranged from $0.17 \pm 0.04$ to $0.24 \pm 0.04$ for body traits, $0.06 \pm 0.03$ to $0.15 \pm 0.04$ for feet and leg traits and from $0.12 \pm 0.04$ to $0.25 \pm 0.05$ for udder traits. Genetic correlations among the recorded type traits ranged from $-0.76 \pm 0.01$ (between $A N$ and RLRV) to $0.65 \pm 0.02$ (between $A N$ and $R W$ ). The low to moderate positive genetic correlations between AN and FUA with milk production traits indicate that cows with high AN and good FUA have higher milk, fat and protein yields. The results of this study indicated that considerable genetic variation exists for different type traits within this sample of the Iranian Holstein population and additive genetic variability of type traits can provide moderate genetic gains through selection.
\end{abstract}

Key words: dairy cattle, genetic parameters, production traits, type traits

The breeding goal in dairy cattle is to increase lifetime profit per animal. Profit is a function of production and the time that a cow remains in herd. Thus, profit can only be recorded when a cow is culled, and breeding value of more profitable ani- 
mals should be able to be predicted by indexes from measurements at an early age of the cow (Pérez-Cabal and Alenda, 2002).

In the past, the most dairy cattle breeding objectives around the world have focused exclusively on production traits. Selection only on yield traits could decrease merit for traits with antagonistic genetic correlations with yield. There is a general consensus that only genetic selection toward increased milk production has reduced the genetic merit for health (Pryce et al., 1998) and fertility (Berry et al., 2003). Several studies have shown that the emphasis of selection for increasing milk production may result in a decrease in the merit of some type traits and influence the health of cows. Therefore, productive life decreases because of udder, reproductive, structural and locomotive disorders (Campos et al., 2012; Pérez-Cabal et al., 2006). Recently, type traits have been associated with production traits; and via selection indexes, they have been used as selection criteria in various countries (Miglior et al., 2005). Like production traits, type traits are an important component of breeding and have definitive importance for breeders in selection of sires (Costa et al., 2005). The most of type traits revealed moderate heritability estimates (Meyer et al., 1987) and can often be recorded in a single scoring, which makes them reliable and relatively inexpensive traits that can be included in selection indices for overall merit (Wiggans et al., 2004). Various studies have been conducted to quantify the importance and the impact of type traits on production traits in dairy cattle (Larroque and Ducrocq, 2001). Therefore, knowing the estimates of (co)variances of type traits is important for the implementation of selection programs. There is a potential to improve type traits of Holstein cattle under Iranian herd environments by selection. Therefore, the objective of this study was to estimate the genetic parameters of type traits in Holstein dairy cattle and relationship among type traits and milk production traits using multi-trait animal model.

\section{Material and methods}

The data originated from seven herds of Holstein dairy cows in Esfahan province of Iran and was collected from 2003 to 2012. The data set included milk yield (MY), fat yield (FY) and protein yield (PY) for the first three lactations, six body traits (stature (ST), chest width (CW), body depth (BD), angularity (AN), rump angle (RA), rump width (RW)), three feet and legs traits (Rear legs side view (RLSV), rear legs rear view (RLRV), foot angle (FA) and eight udder traits (fore udder attachment (FUA), rear udder height (RUH), rear udder width (RUW), central ligament (CL), udder depth (UD), fore teat placement (FTP), rear teat placement (RTP), teat length (TL). Based on visual assessment of the morphology of cows, the phenotypic data of linear type traits was classified on a scale of 1-9. All classifications were carried out by the Arian Delta Gene Company classifiers once during the first lactation; and each

herd was classified by only one classifier. MY, FY and PY had been standardized for twice-daily milking and 305-d lactation length (Sheikhloo et al., 2009). 
We selected common sires that had progeny in more than three herds to create genetic connectedness among herds (Bohlouli et al., 2013). Finally, each sire had at last 10 daughters in data file. Age at calving was from 18 to 30 months for the first lactation; from 32 to 44 months for the second lactation and from 45 to 56 months for the third lactation.

Table 1. Characteristics of pedigree used in computations

\begin{tabular}{lr}
\hline No. of total animals pedigree & 4219 \\
No. of animals with progeny & 3117 \\
No. of animals without progeny & 1048 \\
No. of animals with known parent & 774 \\
No. of sires with progeny & 779 \\
No. of dams with progeny & 4219 \\
\hline
\end{tabular}

Table 2. Descriptive statistics of data set for milk production traits

\begin{tabular}{|c|c|c|c|c|}
\hline Parameter & First lactation & Second lactation & Third lactation & Total \\
\hline \multicolumn{5}{|l|}{ Milk yield (305-d) } \\
\hline no. of records & 2423 & 2317 & 1539 & 6279 \\
\hline means $(\mathrm{kg})$ & 10280.0 & 11586.70 & 11965.80 & \\
\hline SD & 1570.18 & 1993.69 & 1908.92 & \\
\hline minimum & 4614.92 & 4251.07 & 4564.66 & \\
\hline maximum & 15414.0 & 17370.60 & 17371.40 & \\
\hline \multicolumn{5}{|l|}{ Fat yield (305-d) } \\
\hline no. of records & 2420 & 2315 & 1539 & 6274 \\
\hline means $(\mathrm{kg})$ & 356.55 & 415.77 & 440.07 & \\
\hline $\mathrm{SD}$ & 73.83 & 91.90 & 91.10 & \\
\hline minimum & 22.42 & 49.97 & 46.21 & \\
\hline maximum & 537.88 & 675.15 & 607.19 & \\
\hline \multicolumn{5}{|l|}{ Protein yield (305-d) } \\
\hline no. of records & 2142 & 1773 & 1309 & 5224 \\
\hline means $(\mathrm{kg})$ & 303.09 & 357.72 & 401.85 & \\
\hline $\mathrm{SD}$ & 62.82 & 74.47 & 74.97 & \\
\hline minimum & 39.21 & 95.29 & 109.47 & \\
\hline maximum & 502.96 & 501.81 & 480.26 & \\
\hline
\end{tabular}

After applying restrictions, the data file included 2423, 2420 and 2142 records of the first lactation, 2317, 2315 and 1773 records of second lactation and 1539, 1539 and 1309 records of third lactation for milk, fat and protein yields, respectively. For type traits, the data set included 3505 cows of 269 sires and pedigree included 4219 animals. Pedigree and the data are summarized in Tables 1 and 2, respectively. The choice of fixed effects to be considered was made after testing whether the effects were statistically significant with GLM procedure of SAS (Statistical Analysis System, 2003). For type traits, the fixed effects were herd ( 7 herds), age at recording (17 to 31 months, 15 classes) and year of recording (10 classes). For milk production 
traits in the first three lactations, the fixed effects were herd ( 7 herds), age at calving $(13,13$ and 12 classes, respectively for first, second and third lactations) and yearseason at calving (40 classes).

Table 3. Descriptive statistics of data set for type traits

\begin{tabular}{|c|c|c|c|c|c|c|}
\hline \multirow{2}{*}{ Type traits } & & \multicolumn{2}{|c|}{ Score } & \multirow{2}{*}{ Optimum } & \multirow{2}{*}{ Mean } & \multirow{2}{*}{$\mathrm{SD}$} \\
\hline & & 1 & 9 & & & \\
\hline \multicolumn{7}{|l|}{ Body } \\
\hline stature & ST & short & tall & 9 & 6.18 & 1.54 \\
\hline chest width & CW & narrow & wide & 9 & 4.46 & 2.36 \\
\hline body depth & $\mathrm{BD}$ & shallow & deep & 7 & 7.27 & 1.25 \\
\hline angularity & $\mathrm{AN}$ & coarse & angular & 9 & 6.24 & 1.57 \\
\hline rump angle & RA & high pins & low pins & 5 & 4.04 & 2.00 \\
\hline rump width & RW & narrow & wide & 9 & 4.76 & 1.93 \\
\hline \multicolumn{7}{|l|}{ Feet and Legs } \\
\hline rear legs side view & RLSV & straight & sickle & 5 & 5.20 & 1.18 \\
\hline rear legs rear view & RLRV & toe-out & parallel & 9 & 4.76 & 2.52 \\
\hline foot angle & FA & low & steep & 7 & 4.42 & 1.61 \\
\hline \multicolumn{7}{|l|}{ Udder } \\
\hline fore udder attachment & FUA & loose & tight & 9 & 4.51 & 2.79 \\
\hline rear udder height & RUH & low & high & 9 & 4.87 & 2.39 \\
\hline rear udder width & RUW & narrow & wide & 9 & 4.94 & 2.38 \\
\hline central ligament & $\mathrm{CL}$ & weak & strong & 9 & 4.98 & 2.25 \\
\hline udder depth & UD & below & shallow & 5 & 5.30 & 1.56 \\
\hline fore teat placement & FTP & outside of quarter & inside of quarter & 5 & 3.58 & 1.76 \\
\hline rear teat placement & RTP & outside of quarter & inside of quarter & 5 & 5.67 & 2.20 \\
\hline teat length & TL & short & long & 5 & 5.20 & 1.35 \\
\hline
\end{tabular}

Descriptive statistics of milk production traits and type traits are summarized in Tables 2 and 3, respectively. In notation matrix, the following multi-trait animal model was used to estimate variance components:

$$
\left[\begin{array}{c}
\boldsymbol{y}_{1} \\
\vdots \\
\boldsymbol{y}_{20}
\end{array}\right]=\left[\begin{array}{ccc}
\boldsymbol{X}_{1} & 0 & 0 \\
0 & \ddots & 0 \\
0 & 0 & \boldsymbol{X}_{20}
\end{array}\right]\left[\begin{array}{c}
\boldsymbol{b}_{1} \\
\vdots \\
\boldsymbol{b}_{20}
\end{array}\right]+\left[\begin{array}{ccc}
\boldsymbol{Z}_{1} & 0 & 0 \\
0 & \ddots & 0 \\
0 & 0 & \boldsymbol{Z}_{20}
\end{array}\right]\left[\begin{array}{c}
\boldsymbol{a}_{1} \\
\vdots \\
\boldsymbol{a}_{20}
\end{array}\right]+\left[\begin{array}{c}
\boldsymbol{e}_{1} \\
\vdots \\
\boldsymbol{e}_{20}
\end{array}\right]
$$

where $y_{i}$ is observation for $i^{\text {th }}$ trait ( $\mathrm{i}=1$ to 17 for type traits and 18 to 20 for milk production traits of first lactation), $b$ is the a vector of fixed effects, $a$ is the vector of additive genetic effects for $i^{\text {th }}$ trait, $e$ is the vector of random residual effects and $X$, and $Z$ are incidence matrices relating the observations to the fixed and random effects, respectively.

Same model was used to estimate the genetic parameters of milk production traits for the first three lactations ( $i=1$ to 9 for three traits in the first three lactations). 
The following (co)variance structure was assumed for random effects of model:

$$
\operatorname{Var}\left[\begin{array}{c}
a_{1} \\
\vdots \\
a_{20} \\
e_{1} \\
\vdots \\
e_{20}
\end{array}\right]=\left[\begin{array}{cccccc}
g_{1,1} A & \ldots & g_{1,20} A & 0 & \ldots & 0 \\
\vdots & \ddots & \vdots & \vdots & \ddots & \vdots \\
g_{20,1} A & \ldots & g_{20,20} A & 0 & \ldots & 0 \\
0 & \ldots & 0 & r_{1,1} I & \ldots & r_{1,20} I \\
\vdots & \ddots & \vdots & \vdots & \ddots & \vdots \\
0 & \ldots & 0 & r_{20,1} I & \ldots & r_{20,20} I
\end{array}\right]
$$

where $g_{i, i}$ is the additive genetic variance for the direct genetic effect of $i^{\text {th }}$ trait ( $\mathrm{i}=1$ to 20$) ; g_{i, j}(i \neq j)$ is the additive genetic covariance between $i^{\text {th }}$ and $j^{\text {th }}$ traits; $r_{i, i}$ is the residual variance for $i^{\text {th }}$ trait; $g_{i, j}(i \neq j)$ is the residual covariance between $i^{\text {th }}$ and $j^{\text {th }}$ traits. $\boldsymbol{A}$ is the additive genetic relationship matrix and I is an identity matrix for the residual. Heritability estimate for each trait $\left(h^{2}\right)$ was calculated as:

$$
\mathrm{h}^{2}=\frac{\sigma_{a}^{2}}{\sigma_{a}^{2}+\sigma_{e}^{2}}
$$

where $\sigma_{a}^{2}$ and $\sigma_{e}^{2}$ are additive genetic and residual variances, respectively. Additive genetic correlation between $i^{\text {th }}$ and $j^{\text {th }}$ trait $\left(r_{g(i, j)}\right)$ was calculated as:

$$
r_{g(i, j)}=\frac{\operatorname{Cov}_{g(i, j)}}{\sqrt{\operatorname{Var}_{g(i, i)} \times \operatorname{Var}_{g(j, j)}}}
$$

where $\operatorname{Cov}_{g(i, j)}$, is genetic covariance between $i^{\text {th }}$ and $j^{\text {th }}$ trait; $\operatorname{Var}_{g(i, i)}$ and $\operatorname{Var} r_{g(i, j)}$ are additive genetic variance for $i^{\text {th }}$ and $j^{\text {th }}$ trait, respectively. The variance components and standard error were estimated using REML method by WOMBAT software (Meyer, 2007).

\section{Results}

In the third lactation, average yields of MY, FY and PY $(11965.80 \mathrm{~kg}, 440.07 \mathrm{~kg}$ and $401.85 \mathrm{~kg}$, respectively) were higher than the other lactation productions. Phenotypic, genetic and residual variances and heritability estimates for milk production traits (the first three lactations) and for 17 type traits are shown in Table 4 and Table 5 , respectively. Generally, estimated variances increased from the first to the third 
lactation for all traits. Estimated heritability for MY was the lowest in the first lactation period (0.28) and was the highest in the second lactation (0.41); whereas for FY, the highest heritability was 0.36 in the third lactation; and for PY was 0.33 in the second lactation.

The heritability estimates for body traits varied from 0.17 for RW to 0.24 for RA. Heritability estimates for foot and leg traits were $0.06,0.15$ and 0.15 for RLRV, RLSV and FA, respectively; and for udder traits ranged from 0.12 (RUW) to 0.25 (FUA and RTP).

Table 4. Phenotypic $\left(\sigma_{P}^{2}\right)$, genetic $\left(\sigma_{a}^{2}\right)$ and residual $\left(\sigma_{e}^{2}\right)$ variances and heritability $\left(\mathrm{h}^{2}\right)$ for milk production traits

\begin{tabular}{l|c|c|c|c|c}
\hline $\begin{array}{c}\text { Lac- } \\
\text { tation }\end{array}$ & Trait & $\sigma_{P}^{2} \pm \mathrm{SE}$ & $\sigma_{a}^{2} \pm \mathrm{SE}$ & $\sigma_{e}^{2} \pm \mathrm{SE}$ & $\mathrm{h}^{2} \pm \mathrm{SE}$ \\
\hline \multirow{6}{*}{ First } & MY & $2178271.43 \pm 377842.60$ & $610140.00 \pm 114325.30$ & $1568131.43 \pm 316337.24$ & $0.28 \pm 0.05$ \\
& FY & $10585.45 \pm 1361.31$ & $2326.60 \pm 321.36$ & $8258.85 \pm 683.57$ & $0.22 \pm 0.03$ \\
& PY & $4727.42 \pm 682.81$ & $1474.80 \pm 254.30$ & $3252.62 \pm 671.36$ & $0.31 \pm 0.07$ \\
& MY & $3555446.34 \pm 715661.82$ & $1457200.00 \pm 393431.27$ & $2098246.34 \pm 463442.50$ & $0.41 \pm 0.09$ \\
Second & FY & $14498.26 \pm 1534.36$ & $3341.50 \pm 760.87$ & $11156.76 \pm 1542.24$ & $0.23 \pm 0.04$ \\
& PY & $4838.48 \pm 682.55$ & $1593.40 \pm 297.08$ & $3245.08 \pm 891.65$ & $0.33 \pm 0.07$ \\
& MY & $6821257.14 \pm 1020380.50$ & $2387300.00 \pm 414321.65$ & $4433957.14 \pm 705945.62$ & $0.35 \pm 0.06$ \\
Third & FY & $14618.61 \pm 1698.94$ & $5269.90 \pm 1688.28$ & $9348.71 \pm 2156.48$ & $0.36 \pm 0.03$ \\
& PY & $14702.40 \pm 3284.60$ & $3683.10 \pm 728.90$ & $11019.30 \pm 2769.33$ & $0.25 \pm 0.02$ \\
\hline
\end{tabular}

Table 5. Phenotypic $\left(\sigma_{P}^{2}\right)$, genetic $\left(\sigma_{P}^{2}\right)$ and residual $\left(\sigma_{e}^{2}\right)$ variances and heritability $\left(\mathrm{h}^{2}\right)$ for type traits

\begin{tabular}{ll|l|l|l}
\hline \multicolumn{1}{c}{ Type traits } & $\sigma_{P}^{2} \pm \mathrm{SE}$ & $\sigma_{a}^{2} \pm \mathrm{SE}$ & $\sigma_{e}^{2} \pm \mathrm{SE}$ & $\mathrm{h}^{2} \pm \mathrm{SE}$ \\
\hline Body & & & & \\
ST & $1.94 \pm 0.05$ & $0.45 \pm 0.07$ & $1.49 \pm 0.07$ & $0.23 \pm 0.04$ \\
CW & $2.28 \pm 0.06$ & $0.49 \pm 0.10$ & $1.78 \pm 0.09$ & $0.22 \pm 0.04$ \\
BD & $1.46 \pm 0.04$ & $0.26 \pm 0.06$ & $1.21 \pm 0.06$ & $0.18 \pm 0.04$ \\
AN & $2.00 \pm 0.05$ & $0.37 \pm 0.09$ & $1.63 \pm 0.08$ & $0.18 \pm 0.04$ \\
RA & $1.92 \pm 0.05$ & $0.54 \pm 0.09$ & $1.47 \pm 0.09$ & $0.24 \pm 0.05$ \\
RW & $3.28 \pm 0.08$ & $0.55 \pm 0.13$ & $2.73 \pm 0.13$ & $0.17 \pm 0.04$ \\
Feet and Legs & & & & \\
RLSV & $0.55 \pm 0.14$ & $0.08 \pm 0.02$ & $0.46 \pm 0.02$ & $0.15 \pm 0.04$ \\
RLRV & $3.88 \pm 0.21$ & $0.24 \pm 0.12$ & $3.63 \pm 0.14$ & $0.06 \pm 0.03$ \\
FA & $2.26 \pm 0.21$ & $0.35 \pm 0.09$ & $1.91 \pm 0.09$ & $0.15 \pm 0.04$ \\
Udder & & & & \\
FUA & $5.21 \pm 0.21$ & $1.28 \pm 0.25$ & $3.93 \pm 0.23$ & $0.25 \pm 0.05$ \\
RUH & $5.37 \pm 0.13$ & $0.86 \pm 0.21$ & $4.51 \pm 0.21$ & $0.16 \pm 0.04$ \\
RUW & $5.25 \pm 0.13$ & $0.62 \pm 0.19$ & $4.63 \pm 0.20$ & $0.12 \pm 0.04$ \\
CL & $3.88 \pm 0.10$ & $0.53 \pm 0.15$ & $3.35 \pm 0.15$ & $0.14 \pm 0.04$ \\
UD & $1.32 \pm 0.03$ & $0.30 \pm 0.06$ & $1.02 \pm 0.06$ & $0.23 \pm 0.04$ \\
FTP & $2.95 \pm 0.07$ & $0.65 \pm 0.13$ & $2.30 \pm 0.12$ & $0.22 \pm 0.04$ \\
RTP & $4.27 \pm 0.01$ & $1.07 \pm 0.21$ & $3.21 \pm 0.16$ & $0.25 \pm 0.05$ \\
TL & $1.54 \pm 0.04$ & $0.34 \pm 0.07$ & $1.21 \pm 0.07$ & $0.22 \pm 0.04$ \\
\hline
\end{tabular}




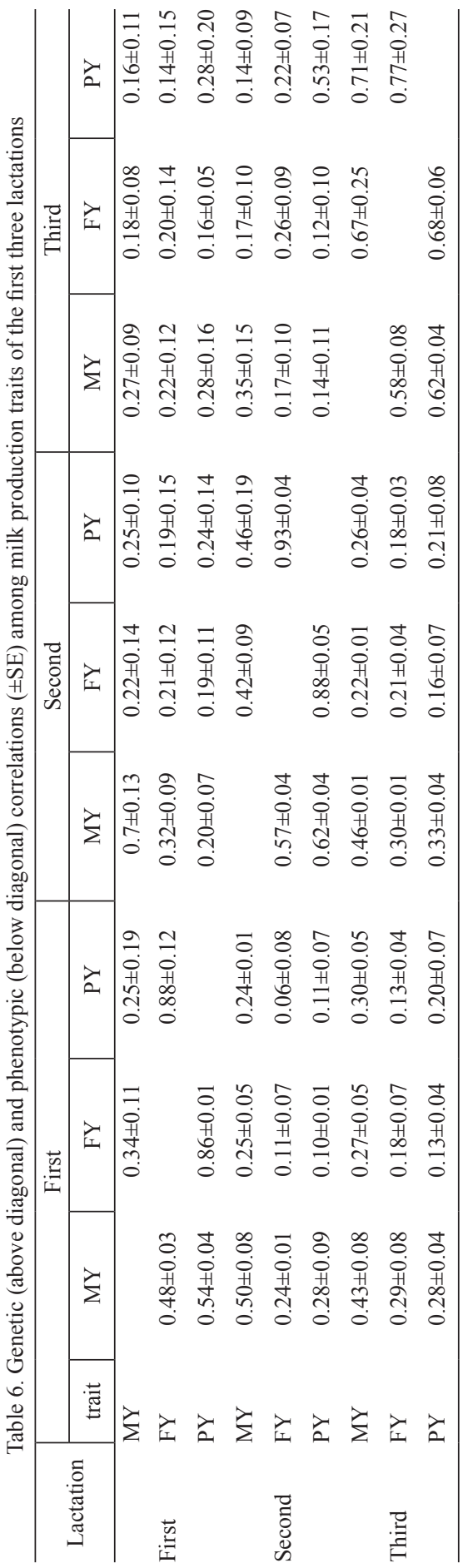




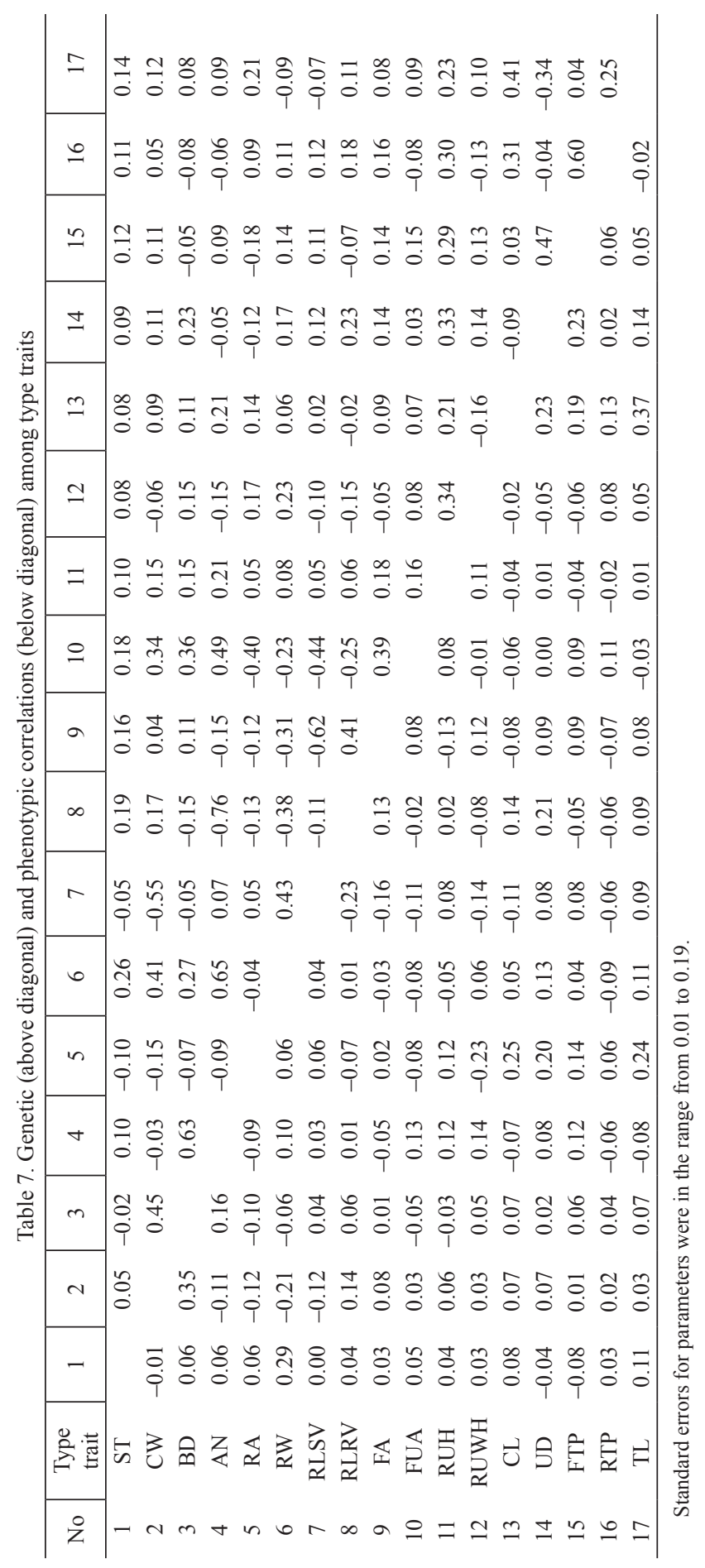


The genetic and phenotypic correlations among the milk production traits are shown in Table 6. All genetic and phenotypic correlations among milk production traits for different lactations were positive.

Among all traits, Genetic correlations between the first and the second lactations ranged from 0.19 to 0.76 and between the first and the third lactations ranged from 0.14 to 0.28 . For the first lactation, genetic correlations between MY and FY, between MY and PY and between FY and PY were 0.34, 0.25 and 0.88 , respectively; and phenotypic correlations were $0.48,0.54$ and 0.86 , respectively. Genetic correlations among production traits within lactations were high; and within lactation, genetic correlations obtained between FY and PY were the largest among all genetic correlation estimates. Genetic correlations obtained between second lactation for FY and PY (0.93) were the largest among all genetic correlation estimates.

Genetic and phenotypic correlations among type traits are shown in Table 7. There are low genetic and phenotypic correlations among several type traits. Generally, phenotypic correlations among the type traits were lower than the genetic correlations. The highest negative phenotypic correlation was observed between RLSV and RLRV ( -0.23$)$, while phenotypic correlation between RTP and TL was positive $(0.61)$.

The highest phenotypic correlation for body traits and feet and legs traits was estimated between CW and RLRV (0.14), and for body and udder traits was estimated between CL and RA (0.25). Genetic correlations ranged from -0.76 (between AN and RLRV) to 0.65 (between AN and RW).

Table 8. Phenotypic and genetic correlations $( \pm \mathrm{SE})$ among milk production traits of the first lactation and type traits

\begin{tabular}{c|c|c|c|c|c|c}
\hline \multicolumn{5}{c}{ Genetic } & \multicolumn{3}{c|}{ Phenotypic } & \multirow{2}{*}{$\begin{array}{c}\text { Correlation } \\
\text { trait }\end{array}$} \\
\hline $0.16 \pm 0.08$ & $0.15 \pm 0.07$ & $0.10 \pm 0.11$ & $0.13 \pm 0.02$ & $0.01 \pm 0.02$ & $0.10 \pm 0.02$ & ST \\
$0.12 \pm 0.14$ & $0.10 \pm 0.19$ & $0.12 \pm 0.09$ & $0.02 \pm 0.02$ & $0.08 \pm 0.02$ & $0.13 \pm 0.02$ & CW \\
$0.18 \pm 0.19$ & $0.15 \pm 0.10$ & $0.14 \pm 0.17$ & $0.15 \pm 0.02$ & $0.16 \pm 0.02$ & $0.10 \pm 0.02$ & BD \\
$0.21 \pm 0.17$ & $0.19 \pm 0.14$ & $0.26 \pm 0.08$ & $0.14 \pm 0.02$ & $0.13 \pm 0.02$ & $0.10 \pm 0.02$ & AN \\
$0.09 \pm 0.13$ & $0.13 \pm 0.19$ & $0.08 \pm 0.14$ & $0.03 \pm 0.03$ & $0.13 \pm 0.02$ & $0.01 \pm 0.02$ & RA \\
$0.10 \pm 0.14$ & $0.09 \pm 0.07$ & $0.05 \pm 0.12$ & $0.07 \pm 0.02$ & $0.07 \pm 0.02$ & $0.05 \pm 0.02$ & RW \\
$0.11 \pm 0.11$ & $0.07 \pm 0.11$ & $0.06 \pm 0.09$ & $0.07 \pm 0.02$ & $0.07 \pm 0.01$ & $0.06 \pm 0.02$ & RLSV \\
$-0.02 \pm 0.12$ & $-0.05 \pm 0.15$ & $0.04 \pm 0.09$ & $0.02 \pm 0.02$ & $-0.05 \pm 0.02$ & $0.01 \pm 0.02$ & RLRV \\
$-0.06 \pm 0.10$ & $-0.08 \pm 0.13$ & $-0.06 \pm 0.11$ & $0.04 \pm 0.01$ & $0.08 \pm 0.03$ & $-0.08 \pm 0.02$ & FA \\
$0.12 \pm 0.05$ & $0.15 \pm 0.08$ & $0.11 \pm 0.14$ & $0.10 \pm 0.02$ & $0.15 \pm 0.02$ & $0.07 \pm 0.02$ & FUA \\
$0.09 \pm 0.08$ & $0.08 \pm 0.04$ & $0.08 \pm 0.05$ & $0.08 \pm 0.02$ & $0.11 \pm 0.02$ & $0.11 \pm 0.02$ & RUH \\
$0.09 \pm 0.07$ & $0.08 \pm 0.07$ & $0.04 \pm 0.14$ & $0.09 \pm 0.03$ & $0.06 \pm 0.02$ & $-0.03 \pm 0.02$ & RUW \\
$0.06 \pm 0.11$ & $0.10 \pm 0.04$ & $0.15 \pm 0.06$ & $0.04 \pm 0.02$ & $0.10 \pm 0.02$ & $0.07 \pm 0.02$ & CL \\
$0.14 \pm 0.10$ & $0.12 \pm 0.03$ & $0.12 \pm 0.09$ & $0.10 \pm 0.02$ & $0.09 \pm 0.02$ & $0.04 \pm 0.02$ & UD \\
$-0.05 \pm 0.14$ & $-0.03 \pm 0.08$ & $0.02 \pm 0.11$ & $0.00 \pm 0.02$ & $-0.03 \pm 0.03$ & $-0.01 \pm 0.02$ & FTP \\
$-0.03 \pm 0.07$ & $0.05 \pm 0.14$ & $0.03 \pm 0.08$ & $0.01 \pm 0.02$ & $0.11 \pm 0.02$ & $0.03 \pm 0.02$ & RTP \\
$0.07 \pm 0.14$ & $0.07 \pm 0.15$ & $0.06 \pm 0.12$ & $-0.09 \pm 0.02$ & $0.13 \pm 0.02$ & $-0.04 \pm 0.02$ & TL \\
\hline
\end{tabular}


Genetic correlations of RW with ST, CW, BD and AN were medium to high and ranged from 0.26 to 0.65 (Table 7). But genetic correlation of RW and RA was close to null. The highest positive genetic correlation for body traits and feet and legs traits was obtained between RW and RLSV (0.43), and for body and udder traits was obtained between AN and FUA (0.49). Among udder traits, FTP and RTP have the highest positive genetic correlation (0.6).

Phenotypic and genetic correlations among milk production traits of the first lactation and type traits are shown in Table 8. The phenotypic correlations among MY and type traits ranged from -0.08 (FA) to $0.13(\mathrm{CW})$; for FY ranged from -0.05 (RLRV) to 0.16 (BD) and for PY ranged from -0.09 (TL) to 0.15 (BD). The highest genetic correlations were estimated among AN and milk production traits and the lowest genetic correlations were estimated between FTP and MY (0.02), between FTP and FY (-0.03) and between RLRV and PY (-0.02). Weak correlations were estimated among udder related traits with MY, FY, and PY. Higher but still low genetic correlations were estimated between FUA and UD with MY, FY, and PY.

\section{Discussion}

\section{Heritability}

Milk production traits

In the current study, the heritability estimations of MY, FY, and PY were similar to those reported by Liu et al. (2014) and Sheikhloo et al. (2009). Although lower heritabilities were reported by DeGroot et al. (2002), similar estimations were reported in the most studies (Zavadilova et al., 2005; Muir et al., 2007). Heritability estimates for MY in the first three lactations $(0.28,0.41$, and 0.35$)$ were similar to the results reported in previously implemented studies on Iranian Holstein cows by Shadparvar and Yazdanshenas (2005), Bohlouli et al. (2013), Mohammadi and Alijani (2014) and Abdullahpour et al. (2013). Estimated heritabilities were higher in comparison with other studies in Tunisian Holsteins (Hammami et al., 2008) and in Polish black and white cattle (Strabel and Jamrozik, 2006). In addition, the heritability estimates were lower in comparison with the results of De Roos et al. (2004). Heritability estimates were reported to be $0.51,0.49$, and 0.47 for MY in the first three lactations by De Roos et al. (2004). These differences may be due to the difference of used models and/or studied cattle population. Heritabilities obtained from the milk production traits of one herd were significantly higher compared to estimated heritabilities of a great number of herds within several provinces (Abdullahpour et al., 2013). For this reason, in circumstances of high diversity of climates, environmental changes and feeding systems, the model might result in greater residual variance and therefore lower heritability (Abdullahpour et al., 2013; Bohlouli et al., 2013).

\section{Type traits}

The heritability estimates of type traits were within the range of most recent studies (Campos et al., 2012; Pérez-Cabal et al., 2006; Zink et al., 2011). Schaeffer et al. (1985) reported heritability estimates between 0.14 and 0.40 for linear type 
traits. They found smaller heritabilities for udder traits than for non-udder traits. The heritability estimates for the type traits varied from 0.24 to 0.43 for UK and Irish data sets (Pérez-Cabal and Alenda, 2002) and these estimations were higher than this study reports.

The high heritability estimated for RA and low heritability for RLRV were similar to those described by Zink et al. (2011). In general, heritability estimates for feet and leg traits $(0.06$ to 0.15$)$ were lower than other type traits. These estimates confirm those reported by Berry et al. (2004) and Zink et al. (2011). The heritability estimate for the udder-related type traits $(0.12$ to 0.25$)$ agree with other estimates for udder type traits (Short et al., 1991; Berry et al., 2004). In the same study by Berry et al. (2003), the heritabilities for the udder-related type traits were from 0.13 to 0.33 . The results indicated that some of traits showed high heritabilities and therefore would show greater responses to selection such as FUA and RTP; and also the heritability of ST and RA were medium ( 0.23 and 0.24 , respectively) and would show medium responses to selection. Campos et al. (2012) reported that greater responses to selection can be achieved for ST and FTP in Holstein cows of Brazil.

For type traits, estimates of heritability can vary significantly according to breed, the classification system, statistical model definitions, number of records per animal and data editing procedures. So comparisons between studies should be done cautiously (Nemcova et al., 2011).

\section{Genetic and phenotypic correlations}

Among milk production traits

For same lactation, phenotypic correlations among milk production traits were the largest among all phenotypic correlations. These trends were similar to those observed in Tunisian (Hammami et al., 2008) and Iranian (Mohammadi and Alijani, 2014; Mohammadi et al., 2014) Holstein dairy cattle.

The largest genetic correlations occurred between the first and the second lactation, and the lowest were observed between the first and the third lactation. Similar correlations were estimated for the same traits in Holstein dairy cows by Hammami et al. (2008) and Jakobsen et al. (2002). With increasing distance between lactations, genes controlling milk productions vary different effects and genetic correlation between traits of two lactations decreased (Zavadilova et al., 2005; Hammami et al., 2008). Accordingly, genetic correlation between MY of the first lactation and FY of the third lactation was lowest (0.16).

\section{Among type traits}

The results of genetic and phenotypic correlations were similar to those observed in previously published studies (Bakhtiarizadeh and Moradi Shahrbabak, 2010; Berry et al., 2004; Nemcova et al., 2011). For some traits, the correlations were close to zero and assert that apparently no important correlation exists among those traits and were in agreement with those obtained by Pérez-Cabal and Alenda (2002). The moderate to high and positive values for genetic correlations between RW and ST (0.26), CW (0.41), BD (0.17) and AN (0.65) indicate that selection for rump width leads to a good genetic improvement in the mentioned traits (ST, CW, BD and AN). Similar results were found by Campos et al. (2012). High genetic correlation between rump 
width and rear legs side view indicated that breeding programs could be successful without one of these traits. This point is possible for all traits that have moderate to high genetic correlations (Campos et al., 2012) such as for AN and FUA traits. For udder traits, low to moderate genetic correlations agree with other estimates for udder-related type traits (Short et al., 1991; Veerkamp and Brotherstone, 1997; Berry et al., 2004; Campos et al., 2012). Estimates among pairs of type traits in this study were slightly smaller than in some studies (e.g. Campos et al., 2012). The strong genetic (0.60) correlation between FTP and RTP indicates the possibility of reducing the number of udder traits assessed on each animal with the loss of very little information. This estimation is slightly stronger than previous reports (DeGroot et al., 2002; Berry et al., 2004). However, estimates from different studies are not directly comparable, mainly because of differences in data sets, models, and the number of traits analyzed.

\section{Among milk production and type traits}

The magnitude and direction of the phenotypic correlations among milk production and type traits in this study were similar to those reported in the other studies (Tapki and Ziya Guzey, 2013; Pahlevan and Moghimi Esfandabadi, 2010). The low to moderate positive genetic correlations among AN and milk production traits indicate that cows with high AN have higher milk and protein yield per lactation than those with lower AN. Other body traits (ST, CW, BD, RA and RW) showed low but positive correlations with milk production traits. In a study on Czech Holstein cows, genetic correlations among MY, FY, and PY with body traits were mostly close to zero; and moderate genetic correlations of those traits with AN were $0.32,0.42,0.34$, respectively (Zink et al., 2014). For the Italian Brown Swiss cattle, Samore et al., (2010) also estimated moderate to low genetic correlations for angularity with MY, FY, and PY (0.36, 0.39, and 0.23, respectively).

Results of relationship among udder type traits and milk production traits were in agreement with previous reports (Campos et al., 2012; Zink et al., 2014). High-yielding cows have deeper udders (Norman et al., 1988). Generally, the genetic correlations showed that higher yielding cows were more $\mathrm{AN}$, have relatively deeper body, deeper udders, good UD and good FUA.

Positive genetic correlations among milk production traits and the body type traits may reflect past emphasis on milk production traits simultaneously with increased cow AN, ST, CW, BD, RA and RW in Holstein breeding programs (Campos et al., 2012; Liu et al., 2014; Zink et al., 2014). Genetic correlations among the udder type traits and milk production traits indicate that genetic selection for increased milk production alone will result in cows with better FUA, RUH, RUW, CL and UD. These results are in agreement with those obtained by Berry et al. (2004). Although more studies reported positive genetic correlations among udder traits and milk production traits, negative genetic correlations were observed by Brotherstone (1994). Based on results of Berry et al. (2004), a combined selection objective including FUA and RA may be warranted to alleviate the deleterious effects of selection on milk production traits.

Lund et al. (1994) reported a positive genetic correlation between angularity and somatic cell count. In this study, due to the moderate correlation between angularity 
and milk production $(0.26)$, more angular cows with low body condition score may be indicative of cows in negative energy balance and may be under greater metabolic stress. This may have deleterious consequences for their immune system making them more susceptible to mammary infections (Berry et al., 2004). Berry et al. (2004) reported that less-angular cows with more body condition and lower pins had lower somatic cell count; and similarly, cows with tighter FUA and stronger udders with shorter, closer teats had lower SCC levels.

Finally, type traits have a direct influence on the management of cows (for example the quality or type of bed) and are related to the profitability of the herd. Although there are unfavorable genetic correlations between angularity and fertility traits (based on previous studies), with management improvements, improvement of milk production traits may be achieved through selection of cows with more angularity (Campos et al., 2012).

On the other hand, reproduction traits are usually unfavorably genetically correlated with milk production traits; and for fertility traits, due to low heritability, direct selection may be inefficient. An alternative way to improve fertility could be through selection for linear type traits that are favorably correlated with reproductive traits (Zink et al., 2011).

\section{Conclusions}

The results from this study indicate that the additive genetic variability of type traits can provide moderate genetic gains through selection. Genetic correlations among some type traits were strong and indicate the opportunity of reducing the number of traits in selection program. The results suggested that emphasis on selection for angularity and udder attachment (with management improvements) would bring benefits to improve milk production. However, there are low and unfavorable genetic relationships among some of type traits. The achieved results suggest that in addition to milk production traits, it may be feasible and economically desirable to include some of type traits in breeding goals of dairy cattle industry; and finally, genetic parameters estimated in this study can be used for genetic evaluation of dairy cattle in Iran; and future research needs to investigate the relationship between reproductive and linear type traits.

\section{References}

Abdullahpour R., Moradi Shahrbabak M., Nejati-Javaremi A., Vaez Torshizi R., Mrode R. (2013). Genetic analysis of milk yield, fat and protein content in Holstein dairy cows in Iran: Legendre polynomials random regression model applied. Archiv. Tierzucht., 48: 497-508.

Bakhtiarizadeh M.R., Moradi Shahrbabak M. (2010). An estimation of the lactation curve parameters through incomplete gamma function and a determination of the genetic relationship between these parameters and udder traits, in Holstein population of Iran (in Persian). J. Iranian Anim. Sci., 41: 1-10.

B erry D.P., Buckley F., Dillon P., Evans R.D., Rath M., Veerkamp R.F. (2003). Genetic relationships among body condition score, body weight, milk yield and fertility in dairy cows. J. Dairy Sci., 86: 2193-2204. 
B erry D.P., B u c k 1 e y F., D i 11 o n P., E van s R.D., R a th M., Ve e r k a m p R.F. (2004). Genetic relationships among linear type traits, milk yield, body weight, fertility and somatic cell count in primiparous dairy cows. Irish J. Agr. Food Res., 43: 161-176.

B ohlouli M., Shodja J., Alijani S., Eghbal A. (2013). The relationship between temperature-humidity index and test-day milk yield of Iranian Holstein dairy cattle using random regression model. Livest Sci., 157: 414-420.

B r o the r st on e S. (1994). Genetic and phenotypic correlations between linear type traits and production traits in Holstein-Friesian dairy cattle. Anim. Prod., 59: 183-187.

C a m p o s R.V., C obu c i J.A., C o s t a C.N., N e to J.B. (2012). Genetic parameters for type traits in Holstein cows in Brazil. R. Bras. Zootec., 41: 2150-2161.

Cos t a C.N., C obu c i J.A., Fre it a s A.F., Te ix e ir a N.M., B a rra R.B., Valloto A.A. (2005). Genetic parameters for type traits of Brazilian Holstein cattle. Proc. 56th Annual Meeting of the EAAP.

De Groot B.J., K e ow n J.F., Van Vleck L.D., Marotz E.L. (2002). Genetic parameters and responses of linear type, yield traits, and somatic cell scores to divergent selection for predicted transmitting ability for type in Holsteins. J. Dairy Sci., 85: 1578-1585.

D e Roos A.P.W., H a rbers A.G.F., D e J ong G. (2004). Random herd curves in a test-day model for milk, fat, and protein production of dairy cattle in the Netherlands. J. Dairy Sci., 87: 2693-2701.

Hammami H., Rekik B., Soyeurt H., Ben Gara A., Gengler N. (2008). Genetic parameters for Tunisian Holsteins using a test-day random regression model. J. Dairy Sci., 91: $2118-2126$

Jakobsen J.H., Madsen P., Jensen J., Pedersen J., Christensen L.G., Sorens e n D.A. (2002). Genetic parameters for milk production and persistency for Danish Holsteins estimated in random regression models using REML. J. Dairy Sci., 85: 1607-1616.

L a rro que H., D u croc q V. (1999). An indirect approach for the estimation of genetic correlations between longevity and other traits. Proc. 4th International Workshop on Genetic Improvement of Functional Traits in Cattle. Interbull Bulletin, 21, Jouy-en-Josas, France, pp. 128-135.

L a r r o que H., D u c r o c q V. (2001). Relationship between type and longevity in the Holstein breed. Gen. Sel. Evol., 33: 39-59.

L i u S.B., Hu ize T., L u Y., Ji an m ing Y. (2014). Genetic parameter estimates for selected type traits and milk production traits of Holstein cattle in southern China. Turk. J. Vet. Anim. Sci., 38 : $552-556$.

Lund T., Migli or F., Dek ker s J.C.M., B urnside E.B. (1994). Genetic relationships between clinical mastitis, somatic cell count, and udder conformation in Danish Holsteins. Livest. Prod. Sci., 39: 243-251.

M e y e r K. (2007). Wombat - a program for mixed model analyses by restricted maximum likelihood. User notes. J. Zhejiang Univ. Sci. B, 8: 815-821, Animal Genetics and Breeding Unit, Armidale.

Meyer K., Brotherstone S., Edwards M.R., Hill W.G. (1987). Inheritance of linear type traits in dairy cattle and correlations with milk production. Anim. Prod., 44: 1-10.

Migli or F., Mu ir B.L., Van D o or m a l B.J. (2005). Selection indices in Holstein cattle of various countries. J. Dairy Sci., 88: 1255-1263.

M o ha m madi A., A lijan i S. (2014). Estimation of genetic parameters and comparison of random regression animal and sire models of production traits in the first three lactation Iranian Holsteins. Biotech. Anim. Husb., 30: 261-279.

Mohammadi A., Alijani S., Daghighkia H. (2014). Comparison of different polynomial functions in random regression model for milk production traits of Iranian Holstein dairy cattle. Ann. Anim. Sci., 14: 55-68.

Muir B.L., Kistemaker G., Jamrozik J., Canavesci F. (2007). Genetic parameters for a multiple-trait multiple-lactation random regression test-day model in Italian Holsteins. J. Dairy Sci., 90: 1564-1574.

Ne m c ova E., S t i p kova M., Zavadilova L. (2011). Genetic parameters for linear type trait in Czech Holstein cattle. Czech J. Anim. Sci., 56: 157-162.

Norman H.D., P ow e 11 R.L., Wright J.R., C a s s ell B.G. (1988). Phenotypic and genetic relationship between linear functional type traits and milk yield for five breeds. J. Dairy Sci., 71: 1880-1896. 
Pahlevan R., Moghimi Es fandabadi A. (2010). Study of production, reproduction and type traits in a Holstein population (in Persian). J. Anim. Sci. (Iran), 3: 1-12.

Pérez-Ca ba 1 M.A., A l enda R. (2002). Genetic relationships between lifetime profit and type traits in Spanish Holstein cows. J. Dairy Sci., 85: 3480-3491.

Pér e z-C a b a 1 M.A., G a r c i a C., G on zale s-R e c i o O. (2006). Genetic and phenotypic relationship among locomotion, type traits, profit, production, longevity and fertility in Spanish dairy cows. J. Dairy Sci., 89: 1776-1783.

Pry c e J.E., E s s l e m on t R.J., Th o m p s on R., Ve er k a m p R.F., Ko s s a ib a ti M.A., S i m m G. (1998). Estimation of genetic parameters using health, fertility and production data from a management recording system for dairy cattle. J. Anim. Sci., 66: 577-584.

S a m or e A.B., Rizzi R., R os s o n i A., B a g n a to A. (2010). Genetic parameters for functional longevity, type traits, somatic cell scores, milk flow and production in the Italian Brown Swiss. Italian J. Anim. Sci., 9: 145-152.

S cha effer G.B., Vin s on W.E., P e a r s on R.E., L ong R.G. (1985). Genetic and phenotypic relationships among type traits scored linearly in Holsteins. J. Dairy Sci., 68: 2984-2988.

S e w a le m A., K is t e m a ker G.J., M i g li or F. (2004). Analysis of the relationship between type traits and functional survival in Canadian Holsteins using a Weibull proportional hazards model. J. Dairy Sci., 87: 3938-3946.

$\mathrm{S}$ had parvar A.A., Yazd a n she n a s M.S. (2005). Genetic parameters of milk yield and milk fat percentage test day records of Iranian Holstein cows. J. Anim Sci., 9: 1231-1236.

Sheikhloo M., Shodja J., Pirany N., Alijani S., Sayadnejad M.B. (2009). Genetic evaluation and calculating daughter yield deviation of bulls in Iranian Holstein cattle for milk and fat yields. Asian-Aust. J. Anim. Sci., 22: 611-617.

S hor t T.H., L a w lor T.J., L e e K.L. (1991). Genetic parameters for three experimental linear type traits. J. Dairy Sci., 74: 2020-2025.

Strabel T., Ja mrozik J. (2006). Genetic analysis of production traits of Polish black and white cattle using large-scale random regression test-day models. J. Dairy Sci., 89: 3152-3163.

Tapki I., Zi y a Guzey Y. (2013). Genetic and phenotypic correlations between linear type traits and milk production yields of Turkish Holstein dairy cows. Greener J. Agri. Sci., 3: 755-761.

Ve erka m p R.F., B rotherstone S. (1997). Genetic correlations between linear type traits, food intake, live weight and condition score in Holstein dairy cattle. Anim. Sci., 64: 385-392.

Wiggans G.R., G engler N., Wright J.R. (2004). Type trait (co)variance components for five dairy breeds. J. Dairy Sci., 87: 2324-2330.

Z a va dilova L., J a m ro zi k J., S c h a e ffer L.R. (2005). Genetic parameters for test-day model with random regressions for production traits of Czech Holstein cattle. Czech J. Anim. Sci., 50: 142-154.

Zink V., Stipkova M., Las sen J. (2011). Genetic parameters for female fertility, locomotion, body condition score, and linear type traits in Czech Holstein cattle. J. Dairy Sci., 94: 5176-5182.

Zink V., Zavadilova L., Lassen J., Stipkova M., Lassen J., Vacek M., Stolc L. (2014). Analyses of genetic relationships between linear type traits, fat-to-protein ratio, milk production traits, and somatic cell count in first-parity Czech Holstein cows. Czech J. Anim. Sci., 59: $539-547$.

Received: 6 IV 2015

Accepted: 29 VII 2015 